\title{
COMPENSATORY SUBSIDY TRANSFERRED TO THE BUDGETS OF VOIVODESHIP SELF-GOVERNMENTS IN THE CONTEXT OF REGIONAL POLICY INSTRUMENTS' COORDINATION ${ }^{1}$
}

\begin{abstract}
Summary
Purpose - The aim of the paper is to consider to what extent a compensatory subsidy transferred to the budgets of voivodeship self-governments can help level fiscal imbalances among voivodeships. The article also aims to determine if and (if it is so) to what extent the rules and procedures related to a compensatory subsidy are coordinated with other instruments of regional policy.

Method research - The paper uses the descriptive method with the elements of legal analysis and examines statistical data relating to the budgets of voivodeship self-governments in Poland during the years 2009-2017.

Description of research - The paper studies the issues connected with construction together with the rules associated with the transfer of compensatory subsidy to voivodeship self-governments in the context of aims and instruments of a regional policy. In individual sections, the author presents the theoretical aspects of regional policy under the conditions of globalization, characterizes the functions and significance of compensatory subsidy for voivodeships in the context of good-governance and attempts to assess the scope of the coordination of the procedures referring to a compensatory subsidy with other instruments of a regional policy.

Results - It has been stated that a compensatory subsidy transferred to the budgets of voivodeships should be considered not only as the source of budget revenues, but also as an instrument of a regional policy. The allocation of public funds to voivodeships takes place by means of numerous autonomous public institutions that use different (and uncoordinated - from the point of view of regional policy) criteria and procedures. This in turn has a negative consequence in the form of excessive dispersion of public funding among voivodeships and in the duplicated realization of public tasks by numerous institutions. Subsequently, it increases the costs of the functioning of the public administration. During the analysis of the rules, procedures and construction of a compensatory subsidy it was shown that this particular financial instrument is neither connected nor coordinated with different instruments of regional policy.
\end{abstract}

Key words: compensatory subsidy, regional policy, intervoivodeship fiscal imbalances

JEL Classification: H76, H72

${ }^{1}$ Article received on 4 June 2019, accepted on 23 July 2019. 


\section{Introduction}

In analyzing the distribution of revenues and public expenditure in particular voivodeships, a compensatory subsidy transferred to the budget of voivodeship selfgovernments ought to be considered as one of the instruments of a regional policy. The major problem in such analyses (apart from the challenges concerning the level of resources of public funds allocated for this type of transfers handed over to the budgets of voivodeship self-governments and the criteria on the basis of which the voivodeship's capability in terms of revenues and expenditure needs are specified) is the issue regarding the coordination of particular groups of transfer revenues of the voivodeship self-government budget with the aims and instruments of the realized regional policy.

The author attempts to determine to what degree compensatory subsidies that are transferred to the budgets of voivodeship self-governments contribute to the leveling of fiscal intervoivodeships imbalances in the context of the realization of regional policy aims. The paper also specifies whether (and if so) how the rules and criteria of transferring a compensatory subsidy from the state budget to a voivodeship self-government budget are coordinated with the rules and procedures of allocating public funds in the regional dimension. Currently these problems are so valid and important that they deserve detailed analysis due to the fact that the selection of criteria and measures on the basis of which compensatory subsidies are transferred to the budgets of voivodeship self-governments requires their adjustment to the holistic consistent concept of supporting the development of voivodeships. This, in principle must take into consideration a number of factors which may impact the income and revenue capabilities of the voivodeship self-government as well as the aims and instruments of the created and realized state regional policy and the cohesion policy of the European Union.

\section{Compensatory subsidy transferred to the budgets of voivodeship self-governments versus the contemporary challenges of the regional policy}

The problem of rising disproportions in the level of the socio-economic development of particular voivodeships and the interrelated fiscal inequalities in Poland result chiefly from various natural conditions. These include: the geographical location, climate conditions and the presence or lack of available raw materials. Other important factors include the historical and cultural conditions, the differences in the degree of industrialization, the state of fixed assets and (as a consequence) the differences in the revenue capability of a voivodeship (tax basis). The consequences of these permanent and frequently objective fiscal inequalities ought not to constitute a burden for the inhabitants of particular voivodeships. Therefore, they should be neutralized (at least partially) among others by transfers in the form of a compensatory subsidy from the state budget to the budget of a voivodeship self-government. 
One of the basic challenges in the activity of government and self-government institutions in Poland aimed at the mitigation of differences in the level of socioeconomic development of voivodeships is the elaboration of procedures regarding the specification of both the level and the rules of allocating public funds among voivodeships that take into consideration the requirements of coordinating the criteria on the basis of which compensatory subsidies are transferred to the budgets of voivodeship self-governments together with the aims and other instruments of the regional policy. Numerous publications concerning the revenues supplementing own revenues of the budgets of local territorial units [comp. Poniatowicz, 2018; Kańduła, 2017; Guziejewska, 2014; Sekuła, 2016] include a thorough analysis of the issues regarding construction of the instruments for leveling the fiscal inequalities between municipalities and regions that includes elements such as the type of the compensatory transfer, the algorithm of calculating the sum of transferred public funds and the criteria of distributing public funds among municipalities and regions. However, only limited analyses exist which review the problems connected with the necessity to coordinate particular compensatory transfers owing to the changes observed in the perception of the aims and instruments of the regional policy [more in: Gorzelak, Smętkowski, 2018]. These changes are principally connected with:

- the recognition of the importance and significance of institutions in the processes of voivodeships' development, taking into consideration the role of transaction costs. Formal institutions (e.g.: laws, acts and regulations) and the informal ones (e.g.: the norms of social dialogue, regional traditions and ethical attitudes) are treated as the key to understanding the contemporary problems of regional development. The inconsistency of formal and informal institutions, which condition the relations and cooperation between a regional self-government and other entities, may create a barrier for the realization of the regional policy. Therefore, attention is paid to the necessity to properly shape the relationship between the government administration and the administration responsible for supporting the development of regions, the elaboration of adequate procedures regarding their functioning and for the optimal construction and coordination of procedures and criteria of distributing public funds from the perspective of the regional policy,

- the consideration of the criterion relating to the benefits of scale in the optimal allocation of public funds. Agglomerations constitute the main driving mechanism of growth, while the role of institutions, both at the level of a self-government and the government is to remove those barriers that hamper concentration (the benefits of scale) and to guarantee access to the concentration areas from the area of the entire region. Nowadays during the formulation of principles of a regional policy, attention is paid to the significant role of metropolies in the policy of development at the regional and central level, while convergence is no longer mentioned in detail. 
- the integrated approach to the realization of the aims of the regional policy. This approach implies the development of functional connections, the combination of endogenic and egzogenic potentials as well as multi-level co-management in the region. While a regional policy has thus far been perceived mainly through the prism of programming at the national level, in the new approach it is viewed as the result of participation by all interested parties,

- the approach directed at the activity and participation of non-governmental organizations, self-government regional and local authorities in the policy of regional development. During the elaboration of the criteria and procedures of the distribution of public funds in the regional dimension, the organs of regional and local self-government possess such powers and elements that create the range of financial autonomy, which in an unprecedented degree should be consistent with dimensions of the management quality such as: democratic legal state, transparency, partnership and both effectiveness and efficiency and should guarantee real subjectivity [further in: Dziemianowicz et al., 2018, pp. 204-219].

Within the mechanisms of fiscal compensation during the analysis of the changes taking place at the beginning of the second decade of the 21st century the compensatory subsidies (which are transferred to the budget of a voivodeship selfgovernment) constitute one of the sources of revenues in the structure of revenues in total as well as the instrument of a regional policy. Therefore, it is crucial to make sure that the rules regarding the transfer of compensatory subsidies to the budgets of voivodeship self-governments are coordinated with the distribution of public funds made by numerous institutions from the point of view of the regional policy. During the realization of a regional policy, a voivodeship self-government recognizes a number of tasks from the following domains: counteracting unemployment and the activation of labour markets, environmental protection, water management, public transport and public roads, education and the public educational system, health care and promotion, culture and the protection of goods as well as social aid. Public tasks in these spheres are financed by other institutions at the government and self-government level. Therefore, the main problem is the coordination from the point of view of the regional policy used in these institutions and also the procedures and criteria utilized in the allocation of public funds among voivodeships. The division of public funds amongst regions, which is made by numerous autonomous public institutions using various criteria of allocation (which are uncoordinated from the perspective of the regional policy) has negative consequences in the excessive dispersal of public funds among regions and in the doubled realization of public tasks by many institutions, which also increases the costs of the functioning of public administration.

In circumstances of limited public funding resources and the permament lack of balance in the sector of public finance, one may consider the activities aimed at consolidation (at the level of voivodeship self-governments) of those public funds that so far have been dispersed in special funds and government institutions 
responsible for public funds in regions as the solution that is beneficial for the coordination of the the regional policy instruments. In the case of multi-level management of the processes of regional development one of the basic problems is the coordination of the rules regarding the transfer of subsidies and grants from the state budget to the budget of voivodeship self-government with the procedures and criteria of distributing public funds accumulated in special funds. The independence of the system of collecting and allocating public funds of particular special funds from other elements of the mechanisms of fiscal mitigation for regions (including the rules and criteria of transferring compensatory subsidies to the budgets of voivodeship self-governments) does not lead to the reduction of intervoivodeship fiscal imbalances. Special funds, which are isolated to a various extent in the systems of public finance of particular countries of the European Union, are in general characterized by alternative (in comparison with the state budget and the budgets of local territorial units) procedures and forms of accumulating and allocating public funds. The procedures imply among others, the withdrawal from rigid budget rules, legislatively guaranteed stable and efficient sources of financing public tasks, noncompliance with the annual budget legislation or the financing of the expenditures of special funds not only from the regularly obtained revenues, but also from the funds accumulated in previous years. However, these basic characteristics regarding the functioning of special funds do not constitute an obstacle for the processes of accumulating and distributing public funds by these funds to be coordinated (at least to a satisfactory degree) from the point of view of the regional policy and the mechanisms of fiscal compensation for regions.

In the mechanisms of the vertical mitigation of intervoivodeship fiscal imbalances in Poland it is important to take into consideration the rules and procedures connected with the allocation of public funds by national agencies. The financial plans of these agencies usually completely overlook the regional aspect of the transfer of public funds from central government institutions to voivodeships. Furthermore, the national agencies (despite performing tasks of a regional nature) do not inform self-government authorities of their action and neither do they initiate more widespread cooperation for the development of a certain region. Additionally, they do not adjust planned activities to the aims of the regional policy of a voivodeship self-government or to the strategy of the region's development. Among others, it may contribute to the fact that from the perspective of the regional policy, the limited resources of public funds are too dispersed and are not focused on the most important, strategic priorities from the perspective of particular regions. In these situations it is probable that the allocation of public funds assigned for regional policy is undertaken at random and subjected to the solution of the current, temporary problems connected with the realization of public tasks in the regional dimension.

In the light of the aforementioned reflections there arises the question on whether (and if so) to what extent the criteria and procedures of transferring compensatory subsidy to the budget (which constitutes the instrument of vertical mitigation of fiscal inequalities among voivodeships) of a voivodeship self- 
government, are coordinated with the rules and criteria used by public institutions responsible for the allocation of public funds among voivodeships.

\section{The functions of a compensatory subsidy taking into consideration the concept of good governance}

In Poland after the establishment of district self-governments in 1998, the formal and legislative bases [Act, 2017; Act, 2018] concerning the rules, criteria and procedures of transfering particular parts of the general subsidy to the budgets of voivodeship self-governments were changed frequently. However, these amendments had a fragmentary, short-term character and did not contribute to the substantial changes relating to the importance and function of the compensatory subsidy in the light of other subsidy parts despite major changes in the construction and importance of the regional part (see: table 1). Meanwhile, at this level of local territorial unit and this group of revenues of voivodeship self-government budget revenues it is necessary to have a more systemic approach which on the one hand takes into consideration the aims and instruments of the regional policy and the assumptions of the national strategy of regional development regarding chiefly the principles of making expenses from the budget of the European Union, the national economy of special funds in the spatial dimension as well as the criteria and principles of transferring revenues to the budgets of municipalities and provinces. The adoption of these assumptions during the elaboration and implementation of formal and legislative solutions connected with the compensatory subsidy for voivodeships would be synonymous with the respect for the addumptions of the concept of good governance [comp. Hausner, 2015]. The concept is based on comanagement and suggests the participation of formal and informal actors in the creation of the institutional order, their activity and involvement in solving the problems related to coordination, organization and management. The concept of good governance implies that in the process of making and implementing decisions, the principle of cohesion will be as important as the principles of transparency, participation, accountability and efficiency. This principle implies the integration in the management of various public policies, both European and national ones as well as between the various levels of public authority. In relation to the formal and legislative solutions regarding the compensatory subsidy, the respect for the principle of cohesion would be connected with the necessity to coordinate the criteria and principles of granting it to voivodeship self-governments with the procedures and criteria of making transfers by government institutions operating for regional development and for the improvement of competitiveness of voivodeships. In such conditions the financial instruments used by these institutions could be more coherent than they are presently, whereas the finance of a voivodeship selfgovernment would enable self-government regional authorities to realize the regional policy in the perspective of many years and with responsibility for the inhabitants and entities running their business activity in a certain territory. 
TABLE 1

The structure of a general subsidy transferred to the budgets of voivodeship self-governments in the years 2013-2017 (in mln PLN)

\begin{tabular}{|l|c|c|c|c|c|}
\hline \multicolumn{1}{|c|}{ Specification } & $\mathbf{2 0 1 3}$ & $\mathbf{2 0 1 4}$ & $\mathbf{2 0 1 5}$ & $\mathbf{2 0 1 6}$ & $\mathbf{2 0 1 7}$ \\
\hline General subsidy & 2639.2 & 2870.0 & 1993.1 & 1964.9 & 2126.9 \\
\hline Educational part & 779.7 & 718.4 & 674.0 & 646.7 & 604.3 \\
\hline Regional part & 735.3 & 914.7 & 323.9 & 317.8 & 379.0 \\
\hline Compensatory part & 1091.6 & 1218.2 & 948.9 & 973.1 & 1113.0 \\
\hline $\begin{array}{l}\text { The supplementation } \\
\text { of the general subsidy }\end{array}$ & 32.7 & 18.7 & 46.4 & 273 & 30.6 \\
\hline
\end{tabular}

Source: [Gospodarka finansowa jednostek..., 2018].

In the hitherto prevailing system of financing voivodeship self-governments, the solutions regarding the construction of a compensatory subsidy have not taken into account the problem connected with the necessity to coordinate the aims and instruments of the regional policy. The regulations of the amended act on the revenues of local territorial units precisely regulate the manner of calculating the basic amount and the supplementary amount as well as the conditions that constitute the basis for making transfer to the budget of a voivodeship selfgovernment. The basic amount (the aim of which is reduce the differences in the tax incomes obtained by the budgets of particular voivodeship self-governments) is received by the voivodeship where the indicator of tax incomes per one inhabitant in a voivodeship has a lower value than the indicator of tax incomes for all the voivodeships. On the other hand, the supplementary amount is received by the voivodeship where the indicator of tax incomes per one inhabitant is lower than $125 \%$ of the indicator of tax incomes for all the voivodeships, while the number of inhabitants is not higher than 3 million. The solution implies that it is chiefly the basic amount of tax incomes per one inhabitant of a voivodeship that constitutes the basis for calculating the supplementary amount, in the situation where this indicator in five voivodeships largely differs from the average indicator for the country contributes to the fact that the functions of a compensatory subsidy may not be realized to a satisfactory degree (see: table 2).

The financial and legislative construction of a compensatory subsidy does not take into consideration the problems connected with the increasing diversification of the revenue potential of particular voivodeship self-governments and the increasing diversification of their expenditure needs (owing to numerous external and internal conditionings) and does not take into account the specific character of the aims and tasks of the regional policy. The sums of the compensatory subsidy's components include only the public funds that are included in the state budget and determined annually in the budget act without any references to specific macroeconomic categories (e.g. GDP, revenues, state budget expenditures) [Patrzałek, 2015, pp. 238-244]. Furthermore, the fact that the construction of the compensatory part of the general subsidy overlooks, among others, elements such as the costs 
connected with the development of transport and regional transport, the voivodeship area or the issues related to the quality of the provided public services etc. contributes to the fact that some voivodeship self-governments do not have satisfactory financial bases to perform the tasks of the regional policy.

TABLE 2

The value of $\mathrm{W}$ indicator and $\mathrm{W}_{\mathrm{w}}$ indicator in the years 2015-2017

\begin{tabular}{|l|c|c|c|}
\hline \multicolumn{1}{|c|}{ Specification: voivodeships } & $\mathbf{2 0 1 5}$ & $\mathbf{2 0 1 6}$ & $\mathbf{2 0 1 7}$ \\
\hline Dolnośląskie & 202.29 & 170.35 & 203.61 \\
\hline Kujawsko-pomorskie & 102.15 & 107.00 & 112.69 \\
\hline Lubelskie & 77.71 & 80.50 & 79.10 \\
\hline Lubuskie & 91.76 & 99.82 & 106.10 \\
\hline Lódzkie & 122.49 & 123.04 & 136.11 \\
\hline Małopolskie & 104.79 & 112.46 & 120.62 \\
\hline Mazowieckie & 258.29 & 279.05 & 308.08 \\
\hline Opolskie & 101.79 & 89.92 & 105.96 \\
\hline Podkarpackie & 75.09 & 82.20 & 86.61 \\
\hline Podlaskie & 75.33 & 71.69 & 78.11 \\
\hline Pomorskie & 141.08 & 146.46 & 147.05 \\
\hline Ślaskie & 116.61 & 125.13 & 130.76 \\
\hline Świętokrzyskie & 68.69 & 73.23 & 80.29 \\
\hline Warmińsko-mazurskie & 71.17 & 74.50 & 79.68 \\
\hline Wielkopolskie & 132.69 & 146.28 & 168.80 \\
\hline Zachodniopomorskie & 91.15 & 94.91 & 101.94 \\
\hline Ww indicator & 132.90 & 137.78 & 150.75 \\
\hline
\end{tabular}

Source: own elaboration on the basis of: [www 1].

The disadvantage of the compensatory part of the general subsidy as the vertical instrument serving the mitigation of fiscal imbalances between the regions is that they are limited solely to the criteria referring to tax revenues of particular voivodeships. In the situation where the structure of tax incomes in the budgets of voivodeship self-governments includes mainly the shares of legal persons in the income tax and to a much smaller degree there are shares of physical persons (the incomes from it are to a large degree dependent on the character of the fiscal policy realized by the government and on the macroeconomic situation of the compensation subsidy) the aims and tasks related to the regional policy are not completed to a satisfactory degree. 
TABLE 3

The share of the compensatory part of the general subsidy in the incomes of the budgets of voivodeship self-governments in the years 2009-2017

\begin{tabular}{|c|c|c|c|c|c|c|c|c|c|}
\hline \multirow[t]{2}{*}{$\begin{array}{l}\text { Specification: } \\
\text { voivodeships }\end{array}$} & \multicolumn{3}{|c|}{ General subsidy } & \multicolumn{3}{|c|}{$\begin{array}{l}\text { Including the } \\
\text { compensatory part }\end{array}$} & \multicolumn{3}{|c|}{$\begin{array}{l}\text { The share of the } \\
\text { compensatory part } \\
\text { in own revenues of } \\
\text { voivodeship self- } \\
\text { governments }\end{array}$} \\
\hline & 2009 & 2016 & 2017 & 2009 & 2016 & 2017 & 2009 & 2016 & 2017 \\
\hline POLAND & 2713.3 & 1964.9 & 2126.9 & 1167.8 & 973.1 & 1112.9 & 18.5 & 13.5 & 15.4 \\
\hline Dolnośląskie & 132.6 & 75.2 & 55.6 & 36.8 & 5.5 & 0 & 6.7 & 0.8 & 0 \\
\hline $\begin{array}{l}\text { Kujawsko- } \\
\text {-pomorskie }\end{array}$ & 2304 & 166.5 & 191.0 & 102.8 & 77.9 & 91.7 & 45.7 & 25.6 & 14.0 \\
\hline Lubelskie & 289.4 & 211.8 & 246.9 & 142.5 & 120.5 & 145.3 & 66.4 & 48.4 & 58.3 \\
\hline Lubuskie & 121.3 & 85.0 & 89.4 & 52.3 & 52.8 & 59.9 & 39.7 & 38.7 & 43.9 \\
\hline Lódzkie & 149.5 & 101.6 & 102.8 & 105.2 & 60.7 & 63.6 & 30.7 & 15.4 & 16,1 \\
\hline Małopolskie & 147.4 & 134.6 & 138.7 & 84.3 & 61.4 & 73.1 & 18.9 & 11.6 & 13.8 \\
\hline Mazowieckie & 243.8 & 93.1 & 91.1 & 0 & 0 & 0 & 0 & 0 & 0 \\
\hline Opolskie & 97.4 & 80.5 & 83.6 & 52.1 & 59.3 & 59.3 & 38.8 & 40.8 & 40.8 \\
\hline Podkarpackie & 293.7 & 217.7 & 232.2 & 136.3 & 117.0 & 113.0 & 57.3 & 40.4 & 39.0 \\
\hline Podlaskie & 142.3 & 126.8 & 141.3 & 84.9 & 82.7 & 90.6 & 64.4 & 62.3 & 68.3 \\
\hline Pomorskie & 110.7 & 74.7 & 87.9 & 45.4 & 32.9 & 42.2 & 14.2 & 8.1 & 10.4 \\
\hline Śląskie & 160.6 & 147.8 & 165.1 & 43.0 & 41.8 & 65.8 & 7.6 & 5.5 & 8.6 \\
\hline Świętokrzyskie & 149.1 & 115.6 & 139.6 & 80.6 & 85.1 & 92.6 & 48.3 & 60.7 & 66.1 \\
\hline $\begin{array}{l}\text { Warmińsko- } \\
\text {-mazurskie }\end{array}$ & 180.9 & 154.5 & 167.8 & 101.8 & 93.3 & 103.8 & 81.2 & 62.2 & 69.2 \\
\hline Wielkopolskie & 89.2 & 55.6 & 56.1 & 7.5 & 0 & 0 & 1.4 & 0 & 0 \\
\hline $\begin{array}{l}\text { Zachodnio- } \\
\text { pomorskie }\end{array}$ & 175.0 & 124.0 & 137.7 & 92.2 & 82.2 & 92.1 & 49.0 & 30.9 & 34.7 \\
\hline
\end{tabular}

Source: own elaboration on the basis of: [Rocznikei statystyczne..., 2009-2017; Gospodarka finansowa..., 2009-2017].

While making an attempt to specify the importance and consequence of the adopted solutions in calculating the sums of the compensatory part of the general subsidy for the incomes of voivodeship self-government revenues one needs to observe in general that the total sum of the compensatory part of the general subsidy transferred annually from the state budget to the budgets of voivodeship self-governments in total in the years 2009-2017 constitutes on average approx. $15.0 \%$ of own revenues and oscillated at $1.1 \mathrm{mld}$ PLN, when the revenues from the general subsidy in that period oscillated at 2.1 bln PLN (see: table 3). In the macroeconomic scale in the years 2009-2017 the value of the compensatory subsidy on average constitutes approx. $0.3 \%$ of the expenditures of the state budget, i.e. as 
the instrument of vertical redistribution of public funds in the regional dimension it is of relatively small significance and at the same time in its present construction it is not coordinated with other instruments of the regional policy and does not sufficiently perform the function of efficient leveling of the financial potential of voivodeship self-governments in Poland. Meanwhile in the macro scale in the situation where the indicator of tax incomes per one inhabitant in Podlaskie, Lubelskie and Warmińsko-Mazurskie voivodeships in the years 2012-2017 oscillated at a level that was three times lower than in Mazowieckie voivodeship, on the one hand the compensatory part of the general subsidy constitutes the basic source of incomes of a voivodeship self-government (Podlaskie, Warmińsko-Mazurskie, Swiętokrzyskie and Lubelskie - more than 60\% of own revenues), while on the other hand (apart from three voivodeships - Mazowieckie, Wielkopolskie, Dolnoślaskie - which are not privileged to receive transfer revenues of this group, for five voivodeship self-governments it is one of the sources that does not exceed $15.0 \%$ of own revenues in the budget of a voivodeship self-government.

TABLE 4

\section{Current expenditures versus estate expenditures per 1 inhabitant of a voivodeship in the years 2015-2017}

\begin{tabular}{|l|c|c|c|c|c|c|}
\hline \multirow{2}{*}{ Voivodeships } & \multicolumn{3}{|c|}{ Current expenditures } & \multicolumn{3}{c|}{ Estate expenditures } \\
\cline { 2 - 7 } & $\mathbf{2 0 1 5}$ & $\mathbf{2 0 1 6}$ & $\mathbf{2 0 1 7}$ & $\mathbf{2 0 1 5}$ & $\mathbf{2 0 1 6}$ & $\mathbf{2 0 1 7}$ \\
\hline POLAND & 242.16 & 259.94 & 255.19 & 201.97 & 86.13 & 112.58 \\
\hline Dolnośląskie & 271.36 & 255.90 & 269.66 & 176.62 & 117.09 & 116.29 \\
\hline Kujawsko-pomorskie & 273.70 & 245.44 & 260.30 & 185.85 & 76.70 & 70.35 \\
\hline Lubelskie & 257.14 & 235.11 & 255.38 & 369.35 & 109.55 & 148.56 \\
\hline Lubuskie & 285.50 & 288.01 & 312.09 & 197.18 & 91.81 & 157.12 \\
\hline Lódzkie & 197.61 & 200.10 & 210.12 & 103.06 & 59.98 & 50.79 \\
\hline Małopolskie & 203.72 & 195.44 & 221.61 & 124.76 & 134.21 & 160.17 \\
\hline Mazowieckie & 303.86 & 345.20 & 332.95 & 180.96 & 73.65 & 94.01 \\
\hline Opolskie & 288.02 & 241.85 & 277.81 & 105.05 & 219.71 & 173.97 \\
\hline Podkarpackie & 242.22 & 232,62 & 273.74 & 381.23 & 56.02 & 156.76 \\
\hline Podlaskie & 277.87 & 235.09 & 258.72 & 505.01 & 80.16 & 181.44 \\
\hline Pomorskie & 222.62 & 238.42 & 255.63 & 124.99 & 66.53 & 103.62 \\
\hline Śląskie & 199.42 & 192.94 & 208.25 & 192.57 & 71.74 & 61.55 \\
\hline Świętokrzyskie & 243.21 & 231.49 & 244.22 & 305.39 & 75.13 & 143.88 \\
\hline $\begin{array}{l}\text { Warmińsko- } \\
\text { mazurskie }\end{array}$ & 284.91 & 262.95 & 285.94 & 374.28 & 57.74 & 77.94 \\
\hline Wielkopolskie & 214.32 & 201.99 & 203.15 & 97.31 & 70.16 & 98.90 \\
\hline Zachodniopomorskie & 294.23 & 268.22 & 249.66 & 163.58 & 87.98 & 184.12 \\
\hline
\end{tabular}

Source: own elaboration on the basis of: [www 2]. 
The analysis of the current and estate expenditures in the budget of voivodeship self-governments per one inhabitant demonstrates clearly that in the voivodeships where the indicator of basic tax incomes per one inhabitant is three times lower than in Mazowieckie, Dolnośląskie and Wielkopolskie voivodeships and the compensatory subsidy amounts to more than $60 \%$ of own revenues the diversification in the level of budget expenditures is considerably smaller. Thus the current expenditures in the budgets of voivodeship self-governments with particularly lower revenue potential oscillate at the level of the current expenditures in the selfgovernment budgets of Dolnoślaskie and Wielkopolskie and 77\% of the expenditures of Mazowieckie voivodeship, whereas the estate expenditures per 1 inhabitant from the budget of voivodeship self-governments with low income potential are much higher (on average by $70 \%$ ) from the estate expenditures of Mazowieckie, Dolnośląskie and Wielkopolskie voivodeships (see: table 4).

A compensatory subsidy transferred to the budgets of voivodeship selfgovernments as the form of vertical redistribution of public funds in the regional dimension should be considered not only as the source of revenues in the budgets of voivodeship self-governments, but also as the instrument of the country's regional policy. In the conditions of decreasing importance of structural funds in the mitigation of development disproportions between voivodeships (after 2020) and in circumstances of increasing inequalities in the level of socio-economic development in voivodeships it is necessary to consider and form such solutions that imply the coordination of the instruments of regional policy and increase the importance of the function played by a compensatory subsidy. The problem of imbalances in the level of subregions' development among voivodeships is becoming particularly important for the finance of a voivodeship self-government because in the conditions of globalization processes the inequalities occurring inside voivodeships require collective action since they deny the meaning of social fairness [Piketty, 2015, pp. 158-159]. In such conditions it is purposeful to extend the scope of the redistributional activity of voivodeship self-government and the function of its budget in the mitigation of development disproportions inside voivodeships.

\section{Conclusions}

In the light of the research conducted it has been shown that a compensatory subsidy as the instrument of vertical mitigation of income inequalities in the budgets of voivodeship self-governments on average in the national scale in the background of the level and structure of state budget expenditures is of minor significance. Additionally, this instrument is not combined and coordinated with other instruments of supporting the development of voivodeships, which affects its efficiency. The criteria on the basis of which there are specified sums of a compensatory subsidy transferred to the budgets of voivodeship self-governments, does not take into consideration the function of voivodeship self-governments connected with their basic task, i.e. with the realization of the regional policy. In the light of these findings it appears that in the financial transfer to the budgets of 
voivodeship self-governments from the state budget it is necessary to take into account (to a larger degree than it has been so far) the function of voivodeship selfgovernments in the realization of the regional policy. In the conditions of increasing disproportions regarding the development of particular voivodeships the interventions of self-governments in the domain of infrastructure of regional character, small and medium-sized enterprises and regional labour markets for using national transfers of compensatory character would efficiently reinforce and supplement the instruments of the macroeconomic policy.

\section{References}

Act, 2017, Ustawa z dnia 27 sierpnia 2009 r. o finansach publicznych, tekst jednolity: Dz.U. 2017 poz. 2077 z późn. zm.

Act, 2018, Ustawa z dnia 13 listopada 2003 r. o dochodach jednostek samorządu terytorialnego, tekst jednolity: Dz.U. 2018 poz. 1530 z późn. zm.

Dziemianowicz R., Kargol-Wasiluk A., Bołtromiuk A., 2018, Samodzielność finansowa gmin w Polsce w kontekśsie koncepcji good governance, „Optimum. Economic Studies” nr 4(94), s. 204-219, DOI: 10.15290/oes.2018.04.94.16.

Gorzelak G., Smętkowski M., 2018, Rozwój regionalny, polityka regionalna, EUROREG, Wydawnictwo Uniwersytetu Warszawskiego, Warszawa.

Gospodarka finansowa jednostek samorzqdu terytorialnego, 2009-2017, GUS, Warszawa.

Gospodarka finansowa jednostek samorzqdu terytorialnego, GUS, Warszawa 2018.

Guziejewska B., 2014, Zewnętrzne źródla finansowania samorzqdu terytorialnego. Teoria a praktyka, Wydawnictwo Uniwersytetu Lódzkiego, Lódź.

Hausner J., 2015, Governance i jego konceptualne podstawy, [w:] Współzarzqdzanie publiczne, Hausner J., Mazur S. (red.), Wydawnictwo Naukowe Scholar, Warszawa.

Kańduła S., 2017, Mechanizmy wyrównywania fiskalnego. Studium empiryczne gmin w Polsce w latach 2004-2014, Wydawnictwo Uniwersytetu Ekonomicznego w Poznaniu, Poznań.

Patrzałek L., 2015, Subwencja ogólna jako instrument korekcyjno-wyrównawczyy w systemie finansów samorzqdu terytorialnego, „Prace Naukowe Uniwersytetu Ekonomicznego we Wrocławiu”, nr 404, s. 238-244, DOI: 10.15611/pn.2015.404.16.

Piketty T., 2015, Ekonomia nierówności, Wydawnictwo Krytyki Politycznej, Warszawa.

Poniatowicz M., 2018, Koncepcja federalizmu fiskalnego w systemie finansów samorzqdu terytorialnego, CeDeWu, Warszawa.

Roczniki statystycz̨ne wojewódz̧tw, 2009-2017, GUS, Warsaw.

Sekuła A., 2016, System subwencjonowania jednostek samorzqdu terytorialnego w Polsce dysfunkcje i posiadane kierunki racjonalizacji, Wydawnictwo Politechniki Gdańskiej, Gdańsk.

www 1, https://mf-arch2.mf.gov.pl/ [date of entry: 02.06.2019].

www 2, https://bdl.stat.gov.pl/BDL/ [date of entry: 02.06.2019]. 